\title{
The Survey Level of Physical Fitness of Football Club of STKIP Taman Siswa Bima
}

\author{
$1^{\text {st }}$ Irfan \\ STKIP Taman Siswa Bima, \\ Lintas Bima-Sumbawa, Indonesia \\ irfanhmt05@gmail.com
}

\begin{abstract}
The objective of this study is to know the level of Vo2max in football players. The type of this study was descriptive qualitative research. Sources of data in this study is to use primary data because the data is taken directly by researchers through Multistage Fitness Test. While secondary data is already available data so that can be obtained more easily and quickly, for example data name and number of football club players STKIP Taman Siswa Bima. The sample in this research was all football club players of STKIP Taman Siswa Bima which amounted to 22 people. Meanwhile, for knowing the endurance of football players, it can be used Vo2max test through Multistage Fitness Test. The result of physical fitness level in this footbal club player is with the average score of very good category of 155.5. The average score of the good category is 291.5, medium category is 283.8 , low category is 239.7 , and the total category is 1069.9. From the results of physical fitness test ability of average players football STKIP Taman Siswa Bima only has a vo2max 40-50, which means players far from the level of physical fitness of national foot ball players that Vo2max reached 60.
\end{abstract}

\section{Keywords—physical fitness level, football}

\section{INTRODUCTION}

Sport is one of the ways to strengthen the development of a country, not only to build the physical but also it needs for sustainable development through the improvement of human resources (HR). Sport has instilled a physical education, and a good moral education towards each other, it can be seen directly through the match held by the government through local, National, and International championships.

This means that sport is very important for the development of human life which is strong and great. With the sport, state will be lifted the dignity, and the social status of athletes will be better in the fans' view and sports lovers, with the sports political lobbies will also be develop well for the progress of a nation.

Sport has a good scope in nowadays so that it undergoes significant changes to social, economic, cultural and political growth as part of the development of the Indonesian. In the recent development there are three sport scopes to filter the candidates of national athletes that we often hear, namely: 1). Education sport, 2). Recreation sport and, 3). Achievement sport.
These three sport scopes are important pillars for National Football development and it is same with the sport of football achievement. We all know that in the world cup soccer championship almost all the citizens of the world focused on one goal of the football game, either among the nobility and the people are all crazy about the grand event of world soccer.

Achievements in sport are not transformed instantly through a series of unclear tests, but sport performance coaching must go through a long series to acquire, and form the soul of the desired athlete, thus the athlete will have a spirit of fighting to decipher the red-white heritage in the International Championship. Because of the national sport as part of promoting / scent the name of Indonesia in the International arena through the brilliant achievement of athletes who are in the region to achieve the goal of achievement, so it is in line with the opinion of [19]. Sports achievement aims to foster and develop the achievement of athletes toward the high achievement. High achievement can be achieved through intensive training and programmed continuously and directed towards all elements of achievement that includes physical conditions, techniques, tactics and mental (psychic). These four elements are integrated into an ability and skill both in individual and a team sports.

Soccer is a sport played actively by over 240 million players besides having spectators whose number reaches billions [15]. When analyzed statistically, the game of soccer has gone through numerous changes over the years. This change caused by popularity and the competitive environments has made soccer a sport which requires more strength, power, endurance, speed, aggressiveness and talent. In turn, this has created the need to increase the performances of soccer players and determine in particular the physiological profiles of soccer players. It has been proven through scientific research that factors such as aerobic and anaerobic efforts, speed, agility, endurance and balance affect the performance dramatically and it is considered that only when the training depends on the physiological basics which affect these factors does the performance of the players increase [22].

Football has the most dominant energy system characteristic used is an anaerobic energy system because 
many players do sprint many times to attack, seize the ball or run to secure their area. But with the length of the time it needs to be supported by the aerobic energy system. Aerobic energy systems require oxygen to be continuously channeled to muscle fibers as aerobic metabolism along with carbohydrates, fats and proteins to be converted by energy.

Soccer growth in popularity over the past 20 years has seen a similar increase for research conducted in all fields of sports science [17]. Soccer has developed at the elite, level much research regarding match performance and training has been conducted [14]. As soccer is a team sport, an efficient organization

Football is a sport that favored, and delighted so much by everybody both the old, young, male and even female. The soccer game shapes humans to be honest with themselves, sportsman fair, fair play, responsible and venture to take decisions. Nowadays the development of football in Indonesia is progressing very rapidly. It can be seen in various corners of the city as well as remote villages, it is very easy to find people who play footbal. Football is very popular in the community because it does not matter about the age, social status, or gender. Because it is not only men who play football right now even women like to play a football.

Football is a very popular soccer game played by two teams, each having eleven members [7]. The football game includes a big ball game. Football is played on grass field by two teams or two teams facing each other. The goal of the game of football is to enter the ball into the opponent's goal as much as possible and defend their own area from the opponent

The characteristics of the game is to play the ball using the foot or with all members of the body except by the arm. Football requires special fitness and strength. It is not a good thing if someone can play greatly in the first 10 minutes, after which he shows his fatigue! During a 1.5hour football game, the players ran on average about 5 miles ( 8 kilometers) with partially run, and fast runs. This distance is not a short distance.

Based on the expert's explanation mentioned above it can be concluded that, soccer is a team game sport that demands quality tactics and techniques as well as a compact cooperation in one team to gain victory. As good as any techniques and tactics that a team has, without a compact cooperation will be difficult to win a game

To support game patterns that have good skills, basic techniques are required in the game of football. There are three types of football game techniques that should be taught to the players [16]. The variation terms used to mention these techniques, they are:

a. Foundation or basic techniques. Techniques are classified as foundation (base) is the most basic training menu or the lowest level.

b. Intermediate or advanced techniques. This technique is an advanced technique or intermediate level required to create relevance between the basic skills and the real playing skills.

c. Game or playing technique. The real football skills that every required by the players before they play against another team, actually.
To support the skills in football, physical fitness is required by the players, because physical fitness is the most important part in the human body, the following will be described the sense of physical fitness.

In general, physical fitness is physical vitality, that is, a person's ability to perform everyday work efficiently without excessive fatigue so that he can still enjoy his spare time [6].

Physical fitness is the ability to carry out everyday tasks diligently and vigilantly, without experiencing the most fatigue and can still enjoy his spare time and face the unexpected things in advance [11].

Physical fitness is also a state that is owned or achieved by someone in relation to the ability to perform physical activity, related to health when physical activity can be done without excessive fatigue." From the above definition can be concluded that physical vitality is a condition of the body with the remaining power capable of performing activities without causing fatigue effects [20].

\section{A. Component of Physical Fitness}

Components contained in physical fitness are:
a. Speed ;
b. Agility;
c. Coordination;
d. Endurance;
e. Balance
f. Flexibility
g. Strength;
h. Power
i. Reaction time [8];

\section{B. Body composition}

The entering of energy into the body in the form of energy must therefore be equal to the expenditure of energy, because energy can not be created or destroyed. The arrangement or use of energy includes (1) the external work performed by the skeletal muscle to move an external object or move the body in an external environment; (2) internal work. It consists of all other energy dependent activities that do not belong to the external workings of cardiac muscle and smooth muscle, glandular secretion, and protein synthesis. Only about $25 \%$ of the chemical energy in the food used to do internal work eventually appears as body heat. The metabolic rate, that is energy expenditure per unit time, is measured in kilocalories of heat produced/hour [5].

Good physical fitness will form a good achievement, if physical fitness is owned by the athlete capable of being supplied by the energy that is done at the time of the sport it will form a very powerful force, thus physical fitness can not be separated from the entry of proper energy to produce efficient motion in physical exercise activity.

From the explanation above can be concluded that physical fitness is the capability and ability of the body to make adjustments or adaptation to physical loading without causing excessive fatigue. The level of physical fitness possessed, can be seen from the ability in physical activity. People who have better physical fitness can carry out their physical, daily, efficient, effective, and 
productive activities without experiencing significant fatigue.

To know the capacity of physical fitness, so one that is measured in sports is Vo2max, thenit will be described the explanation about $\mathrm{Vo} 2 \mathrm{max}$

Vo2max is the speed of oxygen consumption in maximum aerobic metabolism. In State Minister of Youth and Sports Affairs 2005 Vo2max test can be done by using bleep test, it can improve cardiovascular one's physical fitness [8].

According to some experts there are several tests conducted in the Vo2max test which includes the following:

Determination of predicted value of Vo2max by BMI measurement was done using equation by involving age factor, BMI, and SRPA [4]. Predictions on the skinfold method were performed by summing the skin thickness of the triceps, suprailiaca, and abdominal areas measured using skinfold calliper [9]. This amount of the skin fold is used as an input to calculate the percentage of predicted value of Vo2max from body fat percentage

The method of Astrand bike uses a submaximal test in which the subject rides a static bike for a minimum of six minutes with certain loading and in stages [4,21]. It proposes that the treadmill test uses the Balke protocol. VO2max is calculated from the speeding time equation on the running track. In the Hardvard Step Test, respondents climbed the bench up and down as high as \pm 17 inch for a maximum of 5 minutes, then calculated physical fitness index (PFI).

Physical activity is measured using the short form of International PhysicalActivity Questionnaire (IPAQ). Determination of activity level is based on the volume of activity within a certain period of time over the past seven days in METs-minute units (IPAQ Research Committee, 2005). Some statistical tests include Krusskall-Wallis test, Spearman test, and Friedman test used to analyze correlation of BMI factor, gender, and physical activity to the value of Vo2max.

Sharkey is to live a healthy life someone must undergo 7 habits of life, namely:

1. Sport regularly

2. Sleep enough

3. Good breakfast

4. Eat regularly

5. Control weight

6. Free from cigarettes and drugs

7. Not consume alcohol [18].

Maximum oxygen volume is the maximum amount of oxygen obtained by the body when the maximal exertion in exercise, when the body converts food into energy, the greater oxygen consumed the greater the energy or speed produced.

The result of Vo2max level criteria measurement test on Lumajang Football Association member member with 22 subjects studied, the result has average $47,47 \mathrm{ml} /$ $\mathrm{kgBB} /$ minute with good criteria. For good criteria amounted to 3 people with a percentage of $13.64 \%$, then for the level of vo 2 max with good category amounted to 8 people with a percentage of $36.36 \%$, while for the level of Vo2max with moderate category amounted to 11 people with a percentage of $50 \%$ [3].
From the results of research in the school SMK Negeri 1 City Gorontalo athletes soccer students are known that the endurance of cardiovascular athletes berkatagori very less with $100 \%$ percentage, from 23 students athletes football student SMK Negeri 1 city Gorontalo by doing bleep test they can only arrive at the maximum level at the 8th level to 6th (41.8), the lowest one at the 2 nd level to 7 (22.1) [13].

There are several factors that affect the practice and the it's result, if the whole exercise session is done seriously then it does not require the possibility of getting the best results in the following games. On the contrary when all the practice sessions are not seriously done by the players, then the results obtained are not maximal. The basic factor that a football player needs to have is physical fitness, to form a physical that produces skilled energy in playing the ball.

The problem of physical fitness is one that affects the football playerskills of STKIP Taman Siswa Bima, so the players are often not able to balance the physical quality which impact on the seizure of the ball is often won by the opponent team. This is an urgent problem experienced by every team, including the football team of STKIP Taman Siswa Bima in the very youngest age.

Physical fitness in football STKIP Taman Siswa Bima is one that is encouraged to coaching gradually, so that physical fitness is expected to survive on long durations of time, because the game of soccer must provide a good physical.

The urgent factor in the player's field is the physical, physical problems of the players often experience fatigue when sparing with other teams, resulting in an uncontrollable impact when battling the ball with opposing players. Physical is the basic foundation to form peformance of football players.

Seeing this as a coach as well as a coach to maneuver an exercise program that leads to physical improvement, the doses in the exercise continue to be improved in the process of training sessions, so players are no longer physically exhausted in any given exercise. One of the programs to improve the physical players is the Multistage Fitness Test (MFT Bleep) test.

The maximum energy use through an aerobic system that requires oxygen is limited by the maximum speed of the cardiovascular respiratory system in sending oxygen to the muscles, so football players need to have a good Vo2max to supply oxygen to support their activities during the game. Therefore, before determining the training program that will be given, of course, it must be done by a pre-test in advance for the sake of the program to be given and executed exactly in accordance with the conditions of team members. One of the testsis to find out how far the level of Vo2max can be done by performing a Multistage Fitness Test (MFT Bleep). Regarding the consideration in improving the player's physical ability, the researcher wants to conduct a research entitled "Survey of Physical Vitality Level at STKIP Taman Siswa Bima Footbal Club".

Exercise has a good scope in nowadays so that it undergoes significant changes to social, economic, cultural and political growth as part of the development of the Indonesian nation. In the development of sports there 
are three sports scope to filter soccer skills, namely: 1). Education sport, 2). Recreation sport and, 3). Achievement sport. The following will be described in the Sports System Act No. 3 of 2005 Article 18-20. Education sport is organized as the part of the educational process. Recreation sport is done as part of the process of restoring health and fitness. Achievement sport is intended part of the efforts to improve the ability and potential of athletes in order to improve the prestige and dignity of the nation.

Thus the students and lecturers are able to think and work innovatively throughout their life, remembering the challenges in the modern era in nowadays is the advancement of science, technology and human resources of high quality in developed countries. Along with these advances, the college STKIP Taman Siswa Bima responded it well to compete and build achievement through skillful activities in sports achievement both local, national, and not demanding possibilities to the international world.

This responsive attitude makes lecturers at the college of STKIP Taman Siswa Bima to be positive to improve the quality. To realize the quality of quality not only sit on the bench and then teach students in classrooms. However, the culture of quality improvement must be in harmony with the innovation of work through real activity that is one of them is through achievement sport, because the sport of achievement as one to find the identity as well as raise the prestige and the dignity of the college.

The basis of the formation of this club is an integral part of the process of establishing the quality of human resources (HR) students of STKIP Taman Siswa Bima who can compete through achievement sport. Achievement sport is a sport to find the ability and identity as sports enthusiasts. Because the sport needs to be spread in three pillars in the Act of Sports System that are education sport, recreation sport, and achievements sport.

These three basic pillars are absolutely implemented and done by the national athletes, and then supported by the motto of sporting the community and community the sport across the layers of Indonesian society, while the foundations of the formation of this club will be described as follows.

The act enables motivation for the college of STKIP Taman Siswa to facilitate the channeling of soccer talent. Seeing the various developments of the existing sports college, so in 2016, a football club is formed as a place for sports distribution, so early formation of strategic steps to organize instruments recruiting soccer players freely, through physical tests and skills followed in the selection phase. From this stage, it is selected and determined about 22 players who were selected to enter the soccer team of students who joined the selection.

The existence of the football club STKIP Taman Siswa Bima increases through the participation rate at the 2016 Regent Cup tournament. Each Club has a target to get the championship, the target is not excessive, because the sport of achievement is a sport to get champions through positive channels that uphold values of sportsmanlike. Uncertain competitions are the duty and responsibility of the coach / elder in fostering his athletes to be viable, and eager in training, as well as in competition. So from the participation in the competition, football club of STKIP Taman Siswa Bima has not been able to enter the runnerup round.

\section{MATERIALS AND METHOD}

Qualitative data is a source of broad and well-defined descriptive, and contains an explanation of the processes occurring within a narrow range. With qualitative data we can follow and sequence events chronologically, assess cause and effect within the sphere of the minds of the local people, and obtain a rich and useful explanation.

The design of the descriptions research is essentially aimed at providing descriptions with a view to answering research questions.

The type of this research is descriptive qualitative research, to obtain the facts from the existing symptoms, the researcher used the test and measurement. Descriptive is a type of research that provides an overview or description of situation as clarity as possible without any treatment of the object under the study. Surveys are one type of research to find out the opinions of information obtained ofthe study, it can be collected from the entire population and can also be from some of the population.

Source of data in this study is to use primary data because the data is taken directly by the researcher through Multistage Fitness Test (MFT bleep) While secondary data is already available data so that can be obtained more easily and quickly, for example data name and number of football club players of STKIP Taman Siswa Bima.

The sample in this research is all football club players of STKIP Taman Siswa Bima totally 22 people. For the sake of knowing the endurance of soccer players can be used Vo2max test through Multistage Fitness Test (Mft Bleep).

To prove the accuracy of the data in this study, it will be used the test technique (Dany and Arikunto, 2012). MFT goal to measure maximal work of heart and lungs with prediction of VO2Max, test bleep. Which cover:

a. The researcher explained about the procedure of doing MFT bleep test

b. The sample is warming up

c. Distance 20 meters

d. Width of 1 meter per trajectory

e. MFT test stage bleep

- Stand behind the starting line

- Waiting for instruction from playback of MFT bleep test tape

- Do a run with a distance of 20 meters

- Students are not allowed out of the track

- Students should not interfere with other runners

- Assessment of students to run from point 0-20 meters, at first level, and back and forth the first student to run. And so on until the sample is no longer able to continue to run at the next level.

Data analysis in this study is data in the form of quantitative descriptive, which means analyzing the findings in the field about the physical condition of physical fitness through the test Mft bleep football player STKIP Taman Siswa Bima 


\section{RESULTS AND DISCUSSION}

After doing the research then the next process is to describe the results of research on football players of STKIP Taman Siswa Bima as explained below:

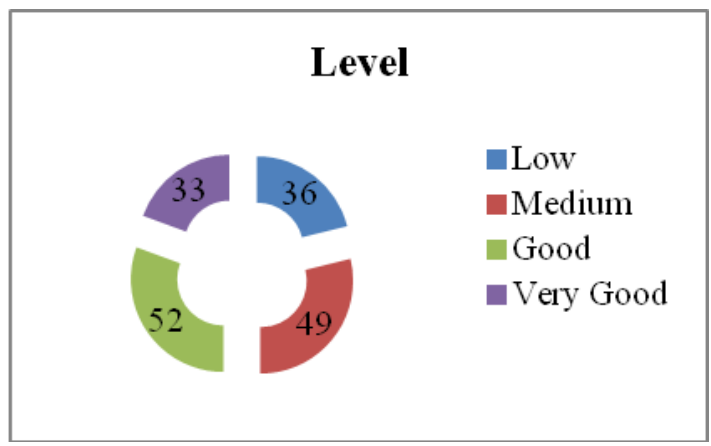

Fig 1. The graphic of soccer playersare based on the level.

The level graphic above shows that the highest student ability for vo 2 max is at level 11 , and at the lowest level is 6 . In the very good level soccer players can only complete a physical fitness level test at level 11 of 3 people with an average of 33. In the good level the soccer player is only able to complete the physical fitness level test at level 9 of 6 people with the average of 52. At a medium level soccer players are only able to complete a physical fitness level test at level 7 of 7 people with the average of 49 . In the low level soccer players can only complete a physical fitness level test at level 6 of 6 people with an average of 36.

In the next discussion will be discussed about the ability back and forth with MFT Bleep test on football players of STKIP Taman Siswa Bima, as described in the following graphic:

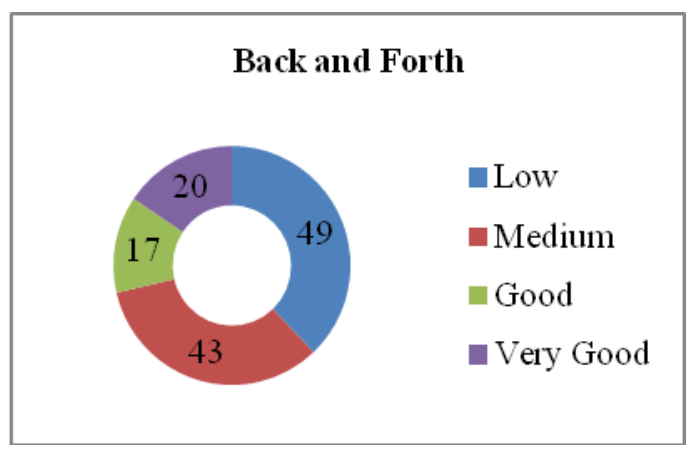

Fig 2. The graphic of soccer players based on the level.

From the graphic above, it shows that the back and forth results of the research using MFT Bleep test through football players of STKIP Taman Siswa Bima are:

1. On the back and forth of the very good category is to get an average score of 20 with the number of 3 players.

2. On the back and forthof good categoryit gets an average score of 17 with the number of 6 players.

3. On the back and forth of the medium category is getting an average score of 43 with the number of 3 players.
4. On the back and forth of the low category get an average score of 49 with the number of 6 players.

To find out vo2max of soccer player of STKIP Taman Siswa Bima as shown in the following graphic:

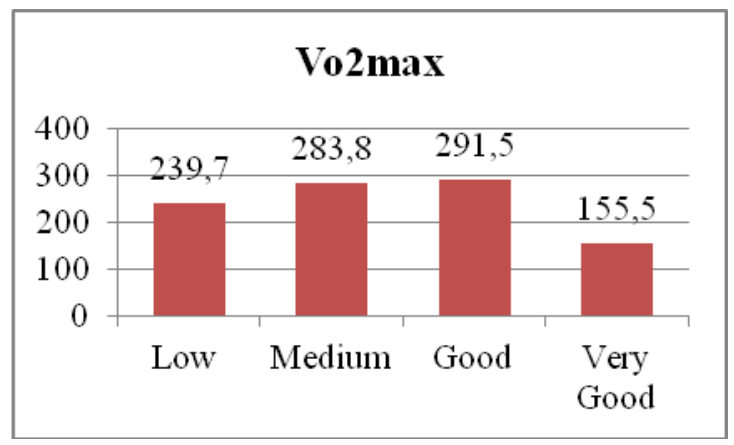

Fig 3. The graphic of soccer players based on vo2max.

From the Vo2max measurement graphic of soccer player of STKIP Taman Siswa Bima above shows the results with the average value of each group, then the average in a very good category are amounted to 155.5 . The average value of each groups in good category, the the average are amounted to 291.5. The average value of each groups in medium category, then the average are amounted to 283.8 . The average value of each groups in the low category, then the average are amounted to 239.7.

Measurement of the results in this study of the physical fitness level of soccer players of STKIP Taman Bima use Multistage Fitness Test (bleep test). So in the results of this study conducted measurements of 22 players experienced different vo2maxin each player, and the average value of the overall subject is 970.5 .

From the results of physical fitness level test of football player of STKIP Taman Siswa Bima the average only has Vo2max 40-50, it means that player is far from the fitness level of the national soccer player that is Vo2max 60. This will affect the performance of the players when competing with other players. Totality, physical endurance can get tired easily with the duration of football game which its intensity is aerobic and anaerobic

\section{CONCLUSION}

From the discussion of physical fitness level of STKIP football player Taman Siswa Bima with MFT Bleep test above, it can be concluded as follows:

1. On the number of soccer players of STKIP Taman Siswa Bima which amounted to 22 people then obtained the average value of vo2max totally 970,5 . The average of the very good category is 155.5 . The average of the good category is 291.5. The average of the medium category is 283.8 . The average of the low category is 239.7 .

2. From the results of physical fitness ability test, the average of players only have a vo 2 max 40-50, it means that players are far away from the level of physical fitness of national football players that their Vo2max reached 60 . 
3. This research can be used as a reference by the trainer or coach to improve the physical condition of the football player, by increasing the dose of exercises.

On the MFT Bleep test is devoted to improve physical conditions, especially in football sport that require long physical endurance, so it will encourage skillful ability in the football game.

\section{REFERENCES}

[1] A. Salim, "Smart book of football", Jembar, Bandung, 2007.

[2] Agung S., R Syaifullah D, S,. "Research methodology of sports", Yuman Pustaka, Surakarta, 2011.

[3] A. Septian et al, "Survey of physical fitness level among fotball players of Lumajang”, retrieved 2016.

[4] Astrand, P.O., Rodahl, K., and Dahl, H.A,. "Textbook of work Physiology Physiological Bases of Exercise Fourth Edition", Human Kinetics, Oslo, 2003.

[5] D. Tohidin, "Physiology development on sports", Wineka Media, Malang, 2010.

[6] Djoko P., "Simple guidance of sports for fitness and health", Andi Offset, Yogyakarta, 2004.

[7] F. Kurniawan, "Smart book of sports: Mens Sana In Corpore Sano", Laskar, Jakarta Aksara, 2011.

[8] G. Wiarto, "Sports physiology", Graha Ilmu, Yogyakarta, 2013

[9] I. Hasanah, "Football”, Indah Jaya Adipratama, Bandung, 2009.

[10] Ipaq Research Committe, "Guidelines for Data Processing and Analysis of The International Physical Activity Questionnaire", IPAQ, 2005.
[11] J. Hairy, "Basic of Sports and Health", National Department of Education, Jakarta, 2010

[12] Pate, Russel R, et al, "Basic of Coaching”, IKIP, Semarang, 1993.

[13] OK. Adnan, "Journal of physical survey among football athletes of SMK Negeri 1 Gorontalo”, 2013.

[14] Bangsbo, J., Mohr, M. and Krustrup, P, "Physiological And Metabolic Demands Of Training And Match Play In The Elite Football Player", Journal of Sports Sciences, vol. (24), pp; 665 674,2006

[15] O. Sever, E. Zorba, "Investigation of Physical Fitness Levels of Soccer Players According to Position and Age Variables", Physical Education and Sport Vol. 15, No 2, 2017, pp. 295 - 307, 2017.

[16] R. Koger, "Basic training of football for teenagers", Saka Mitra Kompetensi, 2007.

[17] Reilly T, Gilbourne D, "Science And Football: A Review of Applied Research In The Football Codes", J Sports Sci 2003 Sep;21(9):693-705, 2003

[18] Suharjana, "Geometric and its characteristic", National Department of Education, Yogyakarta, 2008.

[19] Syarifuddin, "National Journal of Physical Education and Sport Science", Ministry of Sports of Republic Indonesia, Jakarta, 2005.

[20] U. Agustin, "The correlation between body mass index and physical fitness among 12-14 year old", Thesis, Semarang, 2007.

[21] Widaninggar, W.M., Suharto, Soekaptiadi, S., and Hutapea, Jintan, "Know your physical fitness", National Department of Education, Jakarta , 2002.

[22] Weineck, J, “Optimal training performance physiology oriented exercise testing and prescription with particular consideration of training for children and adolescents", Spitta, Balingen, German, 2007.

[23] Regulation for youth and sports, Fokusindo Mandiri, Bandung, 2010 